\section{Evaluating Postharvest Organic Nitrogen Fertilizer Applications in Early Fruiting Northern Highbush Blueberry}

\author{
Amit Bhasin \\ Department of Horticulture, Washington State University, Northwestern Washington \\ Research and Extension Center, 16650 State Route 536, Mount Vernon, WA 98273
}

Joan Davenport

Department of Crop and Soil Sciences, Washington State University, Irrigated Agriculture Research and Extension Center, 24106 North Bunn Road, Prosser, WA 99350

\section{Scott Lukas}

Department of Horticulture, Oregon State University, Hermiston Agricultural Research and Extension Center, 2121 South 1st Street, Hermiston, OR 97838

\section{Qianwen Lu}

Department of Horticulture, Washington State University, Northwestern Washington Research and Extension Center, 16650 State Route 536, Mount Vernon, WA 98273

Gwen Hoheisel

Washington State University Extension, Washington State University, 620 Market Street, Prosser, WA 99350

\section{Lisa W. DeVetter}

Department of Horticulture, Washington State University, Northwestern Washington Research and Extension Center, 16650 State Route 536, Mount Vernon, WA 98273

Additional index words. cold hardiness, fertilizer timing, fruit bud set, liquid fertilizer, nutrient management, Vaccinium corymbosum

Abstract. Bloom to fruit maturity is a period of rapid growth and nitrogen (N) uptake in northern highbush blueberry (Vaccinium corymbosum $\mathbf{L}$.). Sufficient plant-available $N$ is critical during this time, and growers often accomplish this through fertilizer applications from bloom through fruit development. For organic production in northern climates like Washington State, postharvest applications of $\mathbf{N}$ fertilizer are not recommended for northern highbush blueberry because they may stimulate excessive vegetative growth, reduce floral bud set, and increase the risk of winter injury through delayed acclimation. However, early fruiting cultivars with the potential for an extended growing season after harvest may benefit from postharvest $N$ applications because the additional $N$ may promote shoot and root growth that could support fruit production in future years while still allowing plants to form floral buds and acclimate to winter temperatures. The objective of this study was to evaluate the potential impacts of postharvest organic $\mathbf{N}$ fertilizer applications on 'Duke', an early fruiting northern highbush blueberry cultivar. Specific objectives were to determine the effects of postharvest organic $\mathbf{N}$ fertilizer application on plant growth, yield, floral bud set, fruit quality, cold hardiness, tissue macronutrient concentrations, and select soil properties. Four treatments varying in the timing of $\mathrm{N}$ application were evaluated in a commercial 'Duke' field in eastern Washington using a single fertilizer rate of $130 \mathrm{~kg} \cdot \mathrm{ha}^{-1} \mathrm{~N}$ from 2018 to 2020 . The organic fertilizer $\mathrm{N}$ source was a liquid fertilizer derived from digested plant materials. The experimental design was a randomized complete block design with four replications and treatments included the following: control (100\% of $\mathrm{N}$ applied preharvest); $80 / 20$ (80\% preharvest, $20 \%$ postharvest); $70 / 30$ (70\% preharvest, $30 \%$ postharvest); and $60 / 40(60 \%$ preharvest, $40 \%$ postharvest). Although the year influenced measured variables, including yield, floral bud set, fruit quality, tissue nutrients, and soil properties, few treatment effects were observed across the 3-year study. Cold hardiness was only impacted once (8 Feb. 2020), and floral buds were overall hardy to extreme minimum winter temperatures for the region. This project showed that applying postharvest organic $N$ as a liquid fertilizer had no negative consequences on productivity metrics for an early fruiting blueberry cultivar grown in a region with an extended growing season, thus providing growers with more flexibility when timing their fertilizer applications. Results may differ for other fertilizer sources, and further monitoring of soil $\mathrm{NO}_{3}-\mathrm{N}$ accumulation should be conducted to gain a better understanding of its dynamics and the potential for risks.
Optimizing $\mathrm{N}$ fertility in northern highbush blueberry production systems can improve crop yields and reduce production costs and the potential for contamination of surface and/or groundwater through leaching (Throop and Hanson, 1997). However, understanding how $\mathrm{N}$ is cycled within a perennial cropping system is complex because $\mathrm{N}$ taken up by plants during one season can be stored and reused in following seasons. In northern highbush blueberry, rapid $\mathrm{N}$ uptake was observed from late May to late July in Michigan, with most of the $\mathrm{N}$ being directed to aboveground parts such as leaves, stems, and fruits (Throop and Hanson, 1997). This period of $\mathrm{N}$ uptake corresponds to bloom through preharvest or during harvest for some cultivars and growing environments. Throop and Hanson (1997) used ${ }^{15} \mathrm{~N}$ enriched ammonium sulfate to study $\mathrm{N}$ absorption and found that $\mathrm{N}$ derived from fertilizer applied in April, August, and September was mostly stored in roots. These results showed that late bloom to fruit development is a period of high $\mathrm{N}$ demand to support the current season growth. Therefore, ensuring that $\mathrm{N}$ is available for plant uptake from bloom through harvest is recommended.

Nitrogen fertilizer applications during or after harvest are currently not advised for northern highbush blueberry because they may stimulate excessive vegetative growth that can reduce the floral bud set for the next season and increase the risk of winter injury by delaying acclimation (Caruso and Ramsdell, 1995; Hart et al., 2006). However, such outcomes are likely to differ across growing regions and climates. Blueberries planted in regions with a long growing season may have extended summers with 1 to 2 months of additional growth after harvest, depending on the cultivar. Soils with high amounts of organic matter may be able to release $\mathrm{N}$ postharvest to benefit plant growth. However, soils low in organic matter may not effectively release N; therefore, postharvest fertilizer applications may help support late season vegetative growth. Furthermore, early fruiting cultivars have a longer period of potential growth after harvest, and supporting that growth with additional $\mathrm{N}$ through fertilizer applications could be beneficial for shoot development and the development of floral buds for fruit production the next season.

Bañados et al. (2012) used ${ }^{15} \mathrm{~N}$-depleted ammonium sulfate and observed that dry weight allocation and $\mathrm{N}$ derived from fertilizer continues to increase in leaves and shoots after harvest in northern highbush blueberry through September in Oregon. These observations suggest that postharvest fertilization with $\mathrm{N}$ for perennial crops like blueberries may contribute to the $\mathrm{N}$ storage pool in plant tissues and could be used later and reallocated according to plant needs during subsequent years. Abbott and Gough (1987) also observed that the root growth of northern highbush blueberry occurs postharvest as soil 
temperature decreases and becomes more optimal for root growth. Bañados et al. (2012) further noticed that the total $\mathrm{N}$ concentrations and $\mathrm{N}$ derived from fertilizer increased in root tissues during this period, further supporting the idea that postharvest $\mathrm{N}$ applications may be beneficial to some blueberry systems.

The objective of this study was to evaluate the potential impacts of postharvest organic $\mathrm{N}$ fertilizer applications for the early fruiting northern highbush blueberry cultivar Duke. Specific objectives were to determine the effects of postharvest $\mathrm{N}$ fertilizer application on plant growth, yield, fruit quality, floral bud set, cold hardiness, tissue macronutrient concentrations, and select soil properties. It was hypothesized that postharvest $\mathrm{N}$ fertilizer applications would result in increased yields by promoting plant growth from the additional availability of soil $\mathrm{N}$ after harvest. Additionally, it was hypothesized that fruit quality, cold hardiness of floral buds, and tissue macronutrient concentrations would remain the same across fertilizer treatments, whereas soil $\mathrm{N}$ levels measured postharvest would increase with later applications of fertilizer $\mathrm{N}$.

\section{Materials and Methods}

Study site. An on-farm study was established in Prosser, WA, in Feb. 2018, at a commercially managed organic 'Duke' field (lat. $46^{\circ} 16^{\prime} 24.7^{\prime \prime} \mathrm{N}$, long. $\left.119^{\circ} 44^{\prime} 56.5^{\prime \prime} \mathrm{W}\right)$. Soil at the site is classified as a Warden silt loam (coarse-silty, mixed, superactive, mesic Xeric Haplocambids) (U.S. Department of Agriculture Natural Resources Conservation Services, 2019). Plants were in their eighth growing season and were established on raised beds mulched with apple (Malus $\times$ domestica Borkh.) and sweet cherry (Prunus avium L.) wood chips. Planting rows were established in a north-south orientation with plants spaced 0.76 $\mathrm{m}$ apart within the row and $2.7 \mathrm{~m}$ between rows (4873 plants/ha). Plants were grown on $\approx 0.3$-m-tall raised beds that were hilled and had a width of $\approx 0.76 \mathrm{~m}$.

The experimental design was a randomized complete block with four replications. A plot was considered an experimental unit and was $12 \mathrm{~m} \times 0.76 \mathrm{~m}$ with 16 plants. The organic

Received for publication 12 July 2021. Accepted for publication 15 Sept. 2021.

Published online 22 November 2021.

Funding was provided by the Northwest Center for Small Fruits Research and the Washington Blueberry Commission.

Technical assistance provided by Maia Blom, Jenni Suder, Nate Stacey, Emma Rogers, Sean Watkinson, and Prudence Dimakatso Ranphisa is gratefully acknowledged. We are grateful for the support provided by our grower cooperator and to Renee Harkins at WISErg for donation of the fertilizer product. Also, we thank Bernadine Strik, Gabe LaHue, and Margaret McCoy for their input.

L.W.D. is the corresponding author. E-mail: lisa. devetter@wsu.edu.

This is an open access article distributed under the CC BY-NC-ND license (https://creativecommons. org/licenses/by-nc-nd/4.0/). fertilizer source was liquid and derived from digested plant materials $(3 \mathrm{~N}-0.9 \mathrm{P}-1.6 \mathrm{~K}$; WISErganic; WISErg Cooperation, Redmond, WA). The following treatments provided one rate of $\mathrm{N}$ fertilizer $\left(130 \mathrm{~kg} \cdot \mathrm{ha}^{-1} \mathrm{~N}\right)$, but the timing of the postharvest application was varied: control (100\% of $\mathrm{N}$ applied preharvest; standard grower practice); 80/20 (80\% of $\mathrm{N}$ applied preharvest, remaining $20 \%$ applied postharvest); $70 / 30 \quad(70 \%$ of $\mathrm{N}$ applied preharvest, remaining 30\% applied postharvest); and 60/40 (60\% of $\mathrm{N}$ applied preharvest, remaining $40 \%$ applied postharvest). Because the fertilizer product also contained phosphorus $(\mathrm{P})$ and potassium $(\mathrm{K})$, the application timing for these two macronutrients also varied, but the overall rate was kept constant. No additional $\mathrm{P}$ and $\mathrm{K}$ fertilizers were provided during the duration of the study because the baseline soil conditions indicated that these nutrients were at adequate levels (Olsen $\mathrm{P}=104$ ppm and $\mathrm{K}=263$ ppm; measured Mar. 2018) (Mahler and Barney, 2000). Within each year, the control treatment received a total of 10 fertilizer applications (all preharvest), the $80 / 20$ treatment received 12 fertilizer applications (10 preharvest, 2 postharvest), the 70/30 treatment received 14 fertilizer applications (10 preharvest, 4 postharvest), and the 60/40 treatment received 16 fertilizer applications (10 preharvest, 6 postharvest). Because the total $\mathrm{N}$ rate was kept constant, the control, 80/20-treated, 70/30-treated, and 60/ 40-treated plants received weekly fertilizer applications of 2.8, 2.3, 2.0, and $1.7 \mathrm{~g} \mathrm{~N} /$ plant, respectively.

Fertilizer application began at $\approx 5 \%$ to $10 \%$ bloom on 17 Apr. and extended to 22 Aug. in 2018, 25 Apr. to 22 Aug. in 2019, and 9 Apr. to 19 Aug. in 2020. Initiation of fertilizer application was earlier in 2020 because of seasonal effects that advanced crop development. Plants were fertilized by applying the undiluted product around the crown of the plants and near the root zone under the dripline to simulate fertigation. Fertilizer application was intentionally timed to occur immediately before irrigation to dilute the fertilizer. Plants were drip-irrigated daily throughout the growing season using a single line of drip tape suspended on the lower trellis wire. Irrigation scheduling was based on a timer managed by the grower cooperator. Sufficient irrigation water was provided to ensure the fertilizer moved into the root zone but was not leached away. Soil temperature was monitored using HOBO ${ }^{\circledR}$ loggers (Onset Computer, Bourne, MA) installed at a $30-\mathrm{cm}$ depth in the control treatment plots (Fig. 1). Temperature data were recorded every $20 \mathrm{~min}$. Air temperature data were obtained from an AgWeatherNet (http://weather.wsu.edu/) station installed at the Washington State University Irrigated Agriculture Research and Extension Center in Prosser, WA (Fig. 1).

Vegetative growth. Vegetative growth was assessed from the middle 10 plants per plot by counting the number of whips arising from latent buds on 14 June 2018 and 1 June 2019. Whip growth data were not collected in 2020.

Yield and fruit quality. Total yield $(\mathrm{kg} /$ bush) was determined by hand-harvesting all ripe fruits from the center three plants per plot on 26 June 2018, 9 July 2019, and 1 July 2020. Harvest dates were determined based on consultation with the grower cooperator. Approximately $95 \%$ of the fruits on a bush were blue at the time of harvest, except in 2018 , when there was a higher proportion of green fruit. Fruit was weighed on a per-plant basis, providing three plant yield measurements per plot. A random sample of 50 fully ripe berries were sampled from each plot for the analysis of fruit quality. Thirty of the berries were measured for berry mass and firmness within $48 \mathrm{~h}$ of harvest. Berries were weighed on a precision weighing scale (Mettler Toledo PB 303-S/Fact; Mettler Toledo, Columbus, $\mathrm{OH})$. Firmness was measured using a FirmTech II (Bioworks Inc., Wamego, KS) with maximum and minimum compression forces of $200 \mathrm{~g}(1.96 \mathrm{~N})$ and 15 g $(0.15 \mathrm{~N})$, respectively. Piston speed was configured to $6 \mathrm{~mm} \cdot \mathrm{s}^{-1}$. All berries were then frozen at $-23^{\circ} \mathrm{C}$ until additional fruit quality analyses could be conducted. The total soluble solids (TSS) concentrations were determined using a digital refractometer (H19680; Hanna Instruments, Woonsocket, RI) from juice collected after manually crushing the berries and straining through cheesecloth. Titratable acidity (TA) as a percentage of citric acid was measured using a digital titrator (HI-84532, Hanna Instruments).

Floral bud set. To estimate the fruiting potential for the following year, floral bud set was visually determined from 10 laterals per plot on 16 Nov. 2018, 16 Nov. 2019, and 8 Jan. 2021. Floral buds can be visually distinguished from vegetative buds because of differences in size and shape. The following formula was used to measure the floral bud set:

Floral buds/Total buds per lateral $\times 100$

$$
=\% \text { Floral bud set per lateral }
$$

Cold hardiness. The cold hardiness of floral buds was evaluated on 15 Oct. 2018, 18 Nov. 2018, 10 Dec. 2018, 4 Nov. 2019, 18 Nov. 2019, 17 Feb. 2020, 30 Mar. 2020, 26 Oct. 2020, 30 Nov. 2020, and 8 Feb. 2021, using a custom-built programmable freezer (called a "polar pod"). These dates were selected to capture changes in cold hardiness during acclimation and deacclimation. The polar pod machine consisted of individual chambers each wrapped with temperature-controlling heating pads around them to regulate temperature. Samples were removed at intervals of $-1{ }^{\circ} \mathrm{C}$ within predetermined temperature ranges calculated from historical averages that achieved 0 to $100 \%$ floral bud kill. Temperature decreases inside polar pods were achieved gradually to simulate a slow freeze. The polar pod freezing program was set to decrease $-0.5^{\circ} \mathrm{C}$ every $30 \mathrm{~min}$ within -1 to $-4{ }^{\circ} \mathrm{C},-1^{\circ} \mathrm{C}$ every $30 \mathrm{~min}$ from -4 to $-8^{\circ} \mathrm{C}$, and $-2^{\circ} \mathrm{C}$ every $30 \mathrm{~min}$ at $-8^{\circ} \mathrm{C}$ and below. Each pod contained three lateral shoots from each plot, and each lateral contained three fully developed floral buds wrapped in aluminum foil. Lateral shoots were collected from their respective plots in the morning at $\approx 0600 \mathrm{HR}$ and were 

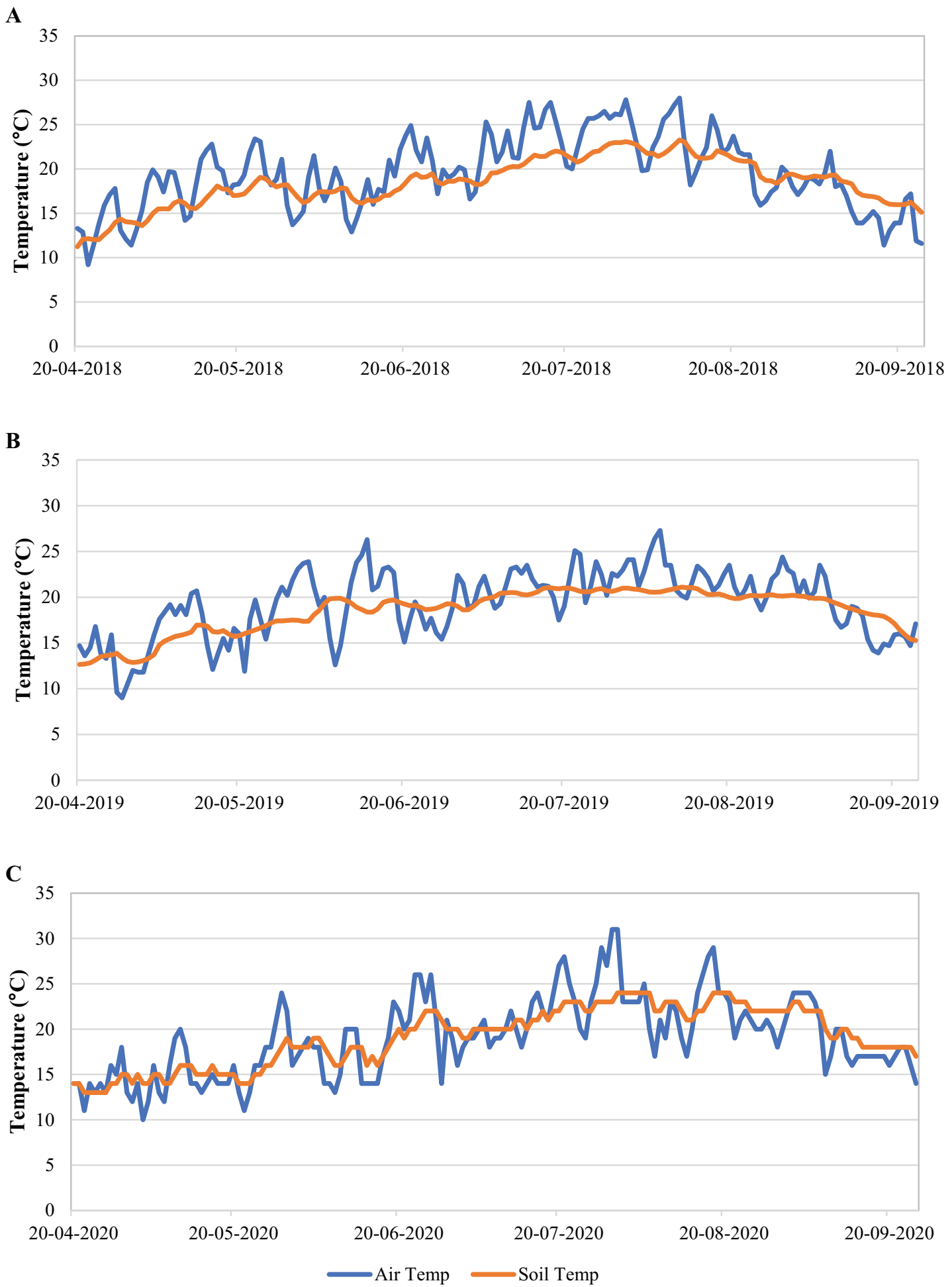

Fig. 1. Average daily soil and air temperature $\left({ }^{\circ} \mathrm{C}\right)$ from 20 Apr. to 25 Sept. in 2018 , 2019, and 2020, in an organic 'Duke' blueberry field in eastern Washington. Air temperature data are courtesy of Washington State University AgWeatherNet. (A) 2018. (B) 2019. (C) 2020.

processed by removing the vegetative buds. Floral buds were exposed to their low temperature treatment for $24 \mathrm{~h}$, thawed for $24 \mathrm{~h}$ at room temperature $\left(21^{\circ} \mathrm{C}\right)$, and later dissected to count the number of dead and alive flowers per bud (Mills et al., 2006).

Leaf nutrient analyses. Leaf tissue samples for nutrient analyses were collected on 13 Aug. 2018, 27 Aug. 2019, and 26 Aug.
2020, from the inner 10 plants per plot. Four fully expanded leaves, two from each side of the plant, were collected from midcanopy height $(n=40$ leaves per plot). Collected leaves were dried at $60^{\circ} \mathrm{C}$ for $48 \mathrm{~h}$ and ground to $<40$ mesh with a Wiley Mill (Thomas Scientific, Swedesboro, NJ). The total $\mathrm{N}$ in leaf tissues was analyzed using a dry combustion method (Sweeney, 1989) and analyzed using a LECO C-N-S analyzer (LECO CHN628; LECO Corporation, St. Joseph, MI). For tissue $\mathrm{P}$ and $\mathrm{K}$, ground leaf tissue was digested with a nitric/perchloric acid solution (Zasoski and Burau, 1977) and analyzed using induced couple plasma atomic emission spectrometry (ICPAES Perkin Elmer Optima 7300 DV; Perkin Elmer, Waltham, MA). 
Soil nutrient analyses. Soil samples were collected four times during the 3-year study. To determine baseline (prefertilizer application) soil conditions, bulk soil samples were collected on 20 Mar. 2018. Composite soil samples were collected at a depth of 0 to 30 $\mathrm{cm}$ with 15 random cores from each block using a soil sampling probe (AMS Inc., American Falls, ID) with an inner core diameter of $2.5 \mathrm{~cm}$. To evaluate the impact of the fertilizer treatments, soil samples were collected on 5 Sept. 2018, 28 Aug. 2019, and 26 Aug. 2020 after completing the fertilizer applications. Sixteen soil cores were collected from soil adjacent to the inner eight plants per plot (eight soil cores on each side of the plants taken within $15 \mathrm{~cm}$ of the plant crown and within the zone of the drip emitters) using the same soil probe and depth as the baseline soil samples. All soil samples were air-dried and sieved through a $<2-\mathrm{mm}$ mesh screen. Soil samples were analyzed for $\mathrm{pH}$ (1:1 soil:water), electrical conductivity (EC; 1:1 soil:water), and concentrations of $\mathrm{NO}_{3}-\mathrm{N}$ and $\mathrm{NH}_{4}-\mathrm{N}$. Soil $\mathrm{NO}_{3}-\mathrm{N}$ and $\mathrm{NH}_{4}-\mathrm{N}$ were determined using a flow injection analyzer (FIAlab; Fluidics Intelligently Automated, Seattle, WA) after extraction with $1 \mathrm{M} \mathrm{KCl}$ (Mulvaney, 1996). No EC data were collected from the baseline samples.

Statistical analysis. All data were analyzed using RStudio (R Statistical and Programming software version 1.1.456; RStudio, Inc., Vienna, Austria). Data were first evaluated for normality and equal variance using the Shapiro-Wilk and Levene's tests, respectively. The median lethal temperature $\left(\mathrm{LT}_{50}\right)$ values were extracted from sigmoidal regressions modeled using cold hardiness data for each fertilizer treatment within a date. Excluding cold hardiness data, the effects of treatment, year, and the treatment $x$ year interaction were analyzed using an analysis of variance followed by Tukey's honestly significant difference post hoc test for multiple comparisons with $\alpha=0.05$. Data are presented by year when there was a significant treatment $x$ year interaction. $\mathrm{LT}_{50}$ values were analyzed within each date. Reciprocal transformation was performed for cold hardiness data from $8 \mathrm{Feb}$. 2021 to improve the normality. All data are presented in their original non-transformed values.

\section{Results and Discussion}

Vegetative growth. No differences in the production of whips per plant were observed across the years and treatments (Table 1). However, in our study, whip production was double that reported by Larco et al. (2013) in a newly established 'Duke' field in Oregon grown with three different mulches (sawdust, sawdust + compost or weed mat) and fertilized with low or high rates of $\mathrm{N}$ fertilizer. Whip production in our study ranged from eight to nine whips per bush. Differences in whip production between these studies could be attributable to plant age because Larco et al. (2013) evaluated recently established plants (2-year-old plants), whereas plants in our study were 8 years old at the initiation of the study. Differences in mulching practices between these studies could also impact whip production from the crown because mulching can act as a physical barrier. Overall, the lack of treatment effects indicates that plants were responding similarly to varied fertilizer application timings.

Yield and fruit quality. A yield response to year was observed, but there was no effect due to fertilizer treatment (Table 1). Yield was greatest in 2020 , averaging $8.4 \mathrm{~kg} /$ bush. Berry mass differed by year and showed a year $\times$ treatment interaction (Table 1). However, when analyzed by year, there was no effect caused by treatment ( $P=0.543,0.142$, and 0.252 for 2018,2019 , and 2020, respectively; data not presented). Berry mass was greatest in 2019, averaging $2.8 \mathrm{~g} /$ berry, and was attributed to a later harvest because delaying picking times and extending harvest intervals have been shown to increase the average berry weight (Strik, 2019).
Firmness only showed a year response, with firmness greatest in 2018, followed by 2020, and with fruit harvested in 2019 having the lowest firmness. Changes in firmness across the years is again attributed to harvest timing and changes in berry mass because smaller berries are firmer. In 2019, berries were allowed to hang on the bushes longer and were harvested later in the season according to the grower cooperator's request. This harvest delay likely caused the decrease in firmness because berries were more ripe, softer, and may have undergone moisture loss, resulting in a loss of firmness (Paniagua et al., 2013; Strik, 2019). However, firmness was comparable to that found by similar studies conducted by Strik et al. (2017b) in western Oregon with 'Duke' under organic production.

Other fruit quality variables were unaffected by treatment. Similar to other variables, TSS and TA differed by year. TSS was greatest in 2019 because of the later harvest, with TA subsequently lower that year as well. TSS is known to increase as TA decreases during blueberry development (Castrejón et al., 2008; Strik, 2019).

Previous studies of both conventional and organic production systems have highlighted that fruit quality traits are influenced by multiple factors, including, but not limited to, cultivar, current season fruit load, plant age, $\mathrm{N}$ fertilizer rate, and method of $\mathrm{N}$ fertilizer application (Strik et al., 2017a; Vargas and Bryla, 2015). For example, Strik and Buller (2014) observed that 'Elliott' northern highbush blueberry grown in Oregon produced smaller and firmer berries when fertilized with higher $\mathrm{N}$ rates. Excessive $\mathrm{N}$ application can also delay fruit development (Bañados et al., 2012). Furthermore, growers manipulate plant structure through pruning to best fit their harvesting method and production goals, which can also influence fruit quality (Strik et al., 2003). Additionally, it is worth noting that variations in fruit quality traits in our study compared with studies conducted in western Oregon could be attributable to the

Table 1. Whip production, yield, floral bud set, berry mass, firmness, total soluble solids, and titratable acidity of 'Duke' blueberry treated with different postharvest organic nitrogen $(\mathrm{N})$ fertilizer application times in eastern Washington, 2018-20.

\begin{tabular}{|c|c|c|c|c|c|c|c|}
\hline Treatments & Whip (no./plant) & Yield (kg/bush) & Floral bud set (\%) & $\begin{array}{l}\text { Berry mass } \\
\text { (g/berry) }\end{array}$ & $\begin{array}{l}\text { Firmness } \\
\left(\mathrm{g} \cdot \mathrm{mm}^{-1}\right. \\
\text { deflection) }\end{array}$ & $\begin{array}{l}\text { Total soluble } \\
\text { solids }(\%)\end{array}$ & $\begin{array}{c}\text { Titratable acidity } \\
(\%)\end{array}$ \\
\hline \multicolumn{8}{|l|}{$\overline{\text { Year }}$} \\
\hline 2020 & $-^{x}$ & $8.4 \mathrm{a}$ & $39 \mathrm{~b}$ & $1.9 \mathrm{~b}$ & $176 \mathrm{~b}$ & $11.7 \mathrm{~b}$ & $0.29 \mathrm{~b}$ \\
\hline \multicolumn{8}{|l|}{ Fertilizer $^{\mathrm{y}}$} \\
\hline Control & 8 & 7.1 & 54 & 2.2 & 178 & 11.7 & 0.29 \\
\hline $60 / 40$ & 9 & 7.9 & 54 & 2.1 & 178 & 12.0 & 0.31 \\
\hline \multicolumn{8}{|l|}{ Significance $^{\mathrm{w}}$} \\
\hline Year (Y) & 0.420 & $<0.0001$ & $<0.001$ & 0.003 & 0.002 & 0.018 & $<0.0001$ \\
\hline Treatment $(\mathrm{T})$ & 0.722 & 0.245 & 0.579 & 0.737 & 0.811 & 0.137 & 0.614 \\
\hline $\mathrm{Y} \times \mathrm{T}$ & 0.756 & 0.703 & 0.630 & 0.005 & 0.851 & 0.067 & 0.424 \\
\hline
\end{tabular}

${ }^{\mathrm{z}}$ Means followed by the same letter within a treatment or interaction are not statistically different $(\alpha=0.05)$.

${ }^{\mathrm{y}}$ Fertilizer treatments that varied in the timing of $\mathrm{N}$ application included a control with $100 \%$ of $\mathrm{N}$ applied preharvest (standard grower practice), $80 / 20$ with $80 \%$ of $\mathrm{N}$ applied preharvest and the remaining $20 \%$ applied postharvest, $70 / 30$ with $70 \%$ of $\mathrm{N}$ applied preharvest and the remaining $30 \%$ applied postharvest, and $60 / 40$ with $60 \%$ of $\mathrm{N}$ applied preharvest and the remaining $40 \%$ applied postharvest.

${ }^{\mathrm{x}}$ Data not collected.

${ }^{\mathrm{w}} P$ value with significance at $\alpha=0.05$. 
Table 2. Mean temperatures $\left({ }^{\circ} \mathrm{C}\right)$ causing $50 \%$ mortality $\left(\mathrm{LT}_{50}\right)$ of 'Duke' blueberry floral buds treated with different organic nitrogen $(\mathrm{N})$ postharvest fertilizer application times in eastern Washington, 2018-20.

\begin{tabular}{|c|c|c|c|c|c|c|c|c|c|c|}
\hline \multirow[b]{2}{*}{ Treatments $\mathrm{z}$} & \multicolumn{3}{|c|}{2018} & \multicolumn{2}{|c|}{2019} & \multicolumn{5}{|c|}{2020} \\
\hline & 15 Oct. & 18 Nov. & 10 Dec. & 4 Nov. & 18 Nov. & $17 \mathrm{Feb}$. & 30 Mar. & 26 Oct. & 30 Nov. & 8 Feb. \\
\hline$\overline{60 / 40}$ & -18.0 & -24.1 & -25.2 & -24.0 & -24.1 & -18.0 & -7.2 & -20.6 & -25.4 & $-22.6 a^{y}$ \\
\hline $70 / 30$ & -17.3 & -27.2 & -25.0 & -23.6 & -23.8 & -17.6 & -7.6 & -20.2 & -25.1 & $-21.5 b$ \\
\hline 100 & -17.8 & -23.4 & -24.4 & -23.9 & -23.8 & -17.5 & -7.0 & -20.6 & -25.5 & $-22.8 \mathrm{ab}$ \\
\hline Significance $^{\mathrm{x}}$ & 0.34 & 0.07 & 0.06 & 0.65 & 0.76 & 0.81 & 0.25 & 0.80 & 0.63 & 0.04 \\
\hline
\end{tabular}

${ }^{\mathrm{z}}$ Fertilizer treatments that varied in the timing of $\mathrm{N}$ application included a control with $100 \%$ of $\mathrm{N}$ applied preharvest (standard grower practice), $80 / 20$ with $80 \%$ of $\mathrm{N}$ applied preharvest and the remaining $20 \%$ applied postharvest), $70 / 30$ with $70 \%$ of $\mathrm{N}$ applied preharvest and the remaining $30 \%$ applied postharvest, and $60 / 40$ with $60 \%$ of $\mathrm{N}$ applied preharvest and the remaining $40 \%$ applied postharvest.

${ }^{\mathrm{y}}$ Means followed by the same letter within a treatment or interaction are not statistically different $(\alpha=0.05)$.

${ }^{\mathrm{x}} P$ value with significance at $\alpha=0.05$.

differences in climatic conditions because eastern Washington is a semi-arid region with hot summers and western Oregon has a warm summer and Mediterranean climate.

Floral bud set. The floral bud set did not differ between treatments (Table 1), but it was lower in 2020. Floral bud set is strongly controlled by cultivar genetics, although environmental factors interacting with cultivar genetics can influence floral bud set (Strik et al., 2017a).

Cold hardiness. Cold hardiness evaluated using $\mathrm{LT}_{50}$ values was the same across all treatments and timepoints except for 8 Feb. 2021 (Table 2). At that timepoint, cold hardiness was greater for floral buds on plants fertilized with the $80 / 20$ fertilizer treatment and lowest for those on plants fertilized with the 70/30 treatment. No other consistent trends attributable to treatment were observed. Therefore, it is unlikely that postharvest $\mathrm{N}$ applications for early fruiting blueberry cultivars will increase winter injury in floral buds by interfering with acclimation and deacclimation processes. Similarly, Naraguma and Clark (1998) found that postharvest $\mathrm{N}$ fertilizer application did not impact the floral bud hardiness of 'Arapaho' thornless blackberry (Rubus L. subgenus Rubus Watson) in Arkansas. Few differences in the floral bud hardiness of 'Anjou' pear (Pyrus communis L.) grown in Washington were also detected when treated with low and moderate rates of fertilizer $\mathrm{N}$ applied in late summer or late winter (Raese, 1997). Furthermore, overall hardiness was high in autumn and winter for trees fertilized in late winter with low $\mathrm{N}$ rates.

Leaf nutrient analyses. Tissue $\mathrm{N}$ and $\mathrm{K}$ differed by year, with $\mathrm{N}$ greatest in 2018 , coinciding with the early sampling time (Table 3 ). Although $\mathrm{N}$ concentrations were lower than regional standards generated for western Oregon $(1.76 \%$ to $2.0 \%$; Hart et al., 2006$)$, concentrations were within the proposed ranges of $1.25 \%$ to $1.75 \%$ for eastern Washington throughout the sampling period (Davenport and DeVetter, 2019). The lack of treatment effects for leaf $\mathrm{N}$ indicates that plants were adequately fertilized and were not taking up more $\mathrm{N}$ than needed, regardless of fertilizer timing. It is also possible that the plants were taking up $\mathrm{N}$ and storing it in other tissues such as roots and stems; however, leaves are important sinks for $\mathrm{N}$ (Bañados et al., 2012). Tissue $\mathrm{K}$ increased since the initiation of the study, with the highest concentrations observed in 2019 and 2020. Although no visual symptoms of toxicity were observed (e.g., chlorosis and stunting), tissue K levels were higher than the proposed sufficiency threshold of $0.5 \%$ for eastern Washington (Davenport and DeVetter, 2019). Increased tissue $\mathrm{K}$ was attributed to continued applications of $\mathrm{K}$ with the WISERganic fertilizer containing $2 \% \mathrm{~K}$. Alternative fertilizers with no $\mathrm{K}$ and cessation of all $\mathrm{K}$ applications are advisable to avoid toxicity caused by excessive $\mathrm{K}$, which blueberry is sensitive to and is correlated with yield reductions (Strik et al., 2019). High concentrations of soil $\mathrm{K}$ from soil-applied amendments can also reduce leaf $\mathrm{Ca}$ and $\mathrm{Mg}$ in blueberry (Eck, 1988; Fageria, 2001; Krewer and Ruter, 2012). No effects were observed for tissue $\mathrm{P}$, and concentrations were within sufficiency ranges (Davenport and DeVetter, 2019).

Soil nutrient analyses. Soil $\mathrm{pH}, \mathrm{NO}_{3}-\mathrm{N}$, and $\mathrm{NH}_{4}-\mathrm{N}$ measured from a composite baseline sample in Mar. 2018 were 6.1, 13.6 $\mathrm{mg} \cdot \mathrm{kg}^{-1}$, and $3.2 \mathrm{mg} \cdot \mathrm{kg}^{-1}$, respectively. Soil $\mathrm{pH}$ decreased thereafter and showed year and treatment responses, with $\mathrm{pH}$ lower in 2019 and 2020 than in 2018 (Table 3). Soils treated with the control had a lower $\mathrm{pH}$ than the $80 / 20$ and $70 / 30$ treatments, whereas the $60 / 40$ treatment was similar to all other treatments. Regardless, soil $\mathrm{pH}$ was less than the 5.5 maximum threshold for northern highbush blueberry

Table 3. Tissue leaf nitrogen $(\mathrm{N})$, phosphorus $(\mathrm{P})$, and potassium $(\mathrm{K})$ content and soil $\mathrm{pH}$ and electrical conductivity (EC) collected from 'Duke' blueberry leaves and soil treated with different postharvest organic nitrogen $(\mathrm{N})$ fertilizer application times in eastern Washington, 2018-20.

\begin{tabular}{|c|c|c|c|c|c|c|c|}
\hline \multirow[b]{2}{*}{ Treatments } & \multicolumn{3}{|c|}{ Plant leaf nutrients $(\%)$} & \multicolumn{4}{|c|}{ Soil variables } \\
\hline & $\mathrm{N}$ & $\mathrm{P}$ & $\mathrm{K}$ & $\mathrm{pH}(1: 1)$ & $\mathrm{EC}(\mathrm{dS} / \mathrm{m})$ & $\mathrm{NO}_{3}-\mathrm{N}(\mathrm{mg} / \mathrm{kg})$ & $\mathrm{NH}_{4}-\mathrm{N}(\mathrm{mg} / \mathrm{kg})$ \\
\hline \multicolumn{8}{|l|}{ Year $^{\mathrm{Z}}$} \\
\hline 2018 & $1.63 \mathrm{a}^{\mathrm{y}}$ & 0.10 & $0.51 \mathrm{~b}$ & $5.36 \mathrm{a}$ & $1.0 \mathrm{~b}$ & $23.5 \mathrm{~b}$ & $6.0 \mathrm{~b}$ \\
\hline 2020 & $1.50 \mathrm{~b}$ & 0.10 & $0.65 \mathrm{a}$ & $5.09 \mathrm{~b}$ & $2.1 \mathrm{a}$ & $49.2 \mathrm{~b}$ & $17.3 \mathrm{a}$ \\
\hline \multicolumn{8}{|l|}{ Fertilizer $^{\mathrm{x}}$} \\
\hline Control & 1.55 & 0.10 & 0.61 & $5.00 \mathrm{~b}$ & 1.7 & 49.8 & 15.6 \\
\hline $60 / 40$ & 1.55 & 0.10 & 0.62 & $5.08 \mathrm{ab}$ & 1.9 & 64.9 & 16.6 \\
\hline \multicolumn{8}{|l|}{ Significance $^{\mathrm{w}}$} \\
\hline Year (Y) & $<0.001$ & 0.184 & $<0.0001$ & 0.014 & 0.002 & 0.049 & 0.012 \\
\hline Treatment $(\mathrm{T})$ & 0.895 & 0.289 & 0.966 & 0.028 & 0.872 & 0.855 & 0.980 \\
\hline $\mathrm{Y} \times \mathrm{T}$ & 0.807 & 0.798 & 0.823 & 0.48 & 0.823 & 0.938 & 0.997 \\
\hline
\end{tabular}

${ }^{\mathrm{z}}$ Leaf tissue samples for tissue nutrient analyses were collected on 13 Aug. 2018, 27 Aug. 2019, and 26 Aug. 2020. Soil samples were collected 5 Sept. 2018, 28 Aug. 2019, and 26 Aug. 2020.

${ }^{\mathrm{y}}$ Means followed by the same letter within a treatment or interaction are not statistically different $(\alpha=0.05)$.

${ }^{\mathrm{x}}$ Fertilizer treatments that varied in the timing of $\mathrm{N}$ application included a control with $100 \%$ of $\mathrm{N}$ applied preharvest (standard grower practice), $80 / 20$ with $80 \%$ of $\mathrm{N}$ applied preharvest and the remaining $20 \%$ applied postharvest, $70 / 30$ with $70 \%$ of $\mathrm{N}$ applied preharvest and the remaining $30 \%$ applied postharvest, and $60 / 40$ with $60 \%$ of $\mathrm{N}$ applied preharvest and the remaining $40 \%$ applied postharvest.

${ }^{\mathrm{w}} P$ value with significance at $\alpha=0.05$. 
(Davenport and DeVetter, 2019; Hart et al., 2006). Maintaining an acidic soil $\mathrm{pH}$ between 4.5 and 5.5 is imperative for successful blueberry production. Growth of plants above this threshold $\mathrm{pH}$ is inhibited and nutrient deficiencies will manifest, with iron being most noticeable (Retamales and Hancock, 2018). The decline in soil $\mathrm{pH}$ over time is likely attributable to the process of nitrification because conversion of $\mathrm{NH}_{4}-\mathrm{N}$ to $\mathrm{NO}_{3}-\mathrm{N}$ is an acidifying process that releases $\mathrm{H}^{+}$into the soil solution (Alexander, 1991). Plants also discharge $\mathrm{H}^{+}$ from roots after $\mathrm{NH}_{4}-\mathrm{N}$ uptake to maintain charge balance inside cells (Marschner, 2011). Various other studies of conventional and organic blueberry production have found that $\mathrm{N}$ application leads to soil acidification (Bañados et al., 2012; Larco et al., 2013), especially for fertilizers containing $\mathrm{NH}_{4}-\mathrm{N}$. According to the fertilizer manufacturer, the WISErganic fertilizer used in this study contains $\approx 29,000$ $\mathrm{mg} \cdot \mathrm{kg}^{-1}$ of total $\mathrm{N}$, with $1260 \mathrm{ppm} \mathrm{NO}_{3}-\mathrm{N}$ and 9 ppm of $\mathrm{NH}_{4}-\mathrm{N}$ (Renee Harkins, personal communication). The remaining $\mathrm{N}$ that is not $\mathrm{NO}_{3}-\mathrm{N}$ or $\mathrm{NH}_{4}-\mathrm{N}$ is from amino acids and other organic compounds, which can mineralize and undergo nitrification to release $\mathrm{H}^{+}$.

EC only showed a year response and was greater in 2019 and 2020. Blueberry is sensitive to high EC levels, which can increase over time if fertilizers and other amendments are high (Larco et al., 2013; Sullivan, 2015; Vargas and Bryla, 2015). Although no discernible effects of increased EC levels were observed in the study, a grower in this situation would be advised to select fertilizer sources with lower EC values and to monitor EC to avoid the potential for continued increases and subsequent problems. Soil EC levels can also be reduced by irrigating with low-salinity irrigation water and washing soluble salts beyond the plant rooting depth (Natural Resources Conservation Service, 2011).

Soil $\mathrm{NO}_{3}-\mathrm{N}$ and $\mathrm{NH}_{4}-\mathrm{N}$ varied by year, but not by treatment (Table 3). Although not included in statistical comparisons because of differences in sampling time, baseline levels were substantially lower than those of samples taken in late summer. Samples collected in late summer showed that soil $\mathrm{NO}_{3}-\mathrm{N}$ was greater in 2019 than in 2018 and 2020, whereas soil $\mathrm{NH}_{4}-\mathrm{N}$ was greater in 2019 and 2020 than in 2018. Although soil $\mathrm{NO}_{3}-\mathrm{N}$ levels are relatively high compared with other northern highbush blueberry production regions (Larco et al., 2013), they are not a function of treatment and are typical for the region (Bair et al., 2008; Davenport et al., 2012). From a nutrient management perspective, a greater proportion of $\mathrm{NH}_{4}-\mathrm{N}$ should be supplied as a source of $\mathrm{N}$ for blueberry because plants preferentially use $\mathrm{NH}_{4}-\mathrm{N}$ over $\mathrm{NO}_{3}-\mathrm{N}$ (Korcak, 1988). In fact, comparative studies have shown $30 \%$ to $60 \%$ reductions in blueberry plant growth when fertilized with $\mathrm{NO}_{3}-\mathrm{N}$ over $\mathrm{NH}_{4}-\mathrm{N}$ (Claussen and Lenz, 1999; Poonnachit and Darnell, 2004).

\section{Conclusions}

This study showed postharvest $\mathrm{N}$ fertilizer applications for an early fruiting northern highbush blueberry cultivar had few impacts on plant growth, yield, fruit quality, floral bud set, cold hardiness, tissue nutrient concentrations, and select soil properties in a region with an extended growing season. Although increases in yield and fruit quality were not observed, the lack of negative effects on floral bud set and cold hardiness indicates that growers can practice more flexibility with their organic liquid $\mathrm{N}$ fertilizer timing and extend the application period postharvest without consequence to productivity metrics. Additionally, soil $\mathrm{NO}_{3}-\mathrm{N}$ and $\mathrm{NH}_{4}-\mathrm{N}$ concentrations did not increase with later fertilizer application timings relative to the control, indicating that late fertilizer application does not increase the potential for negative environmental consequences because of $\mathrm{N}$ leaching within the timeframe of our study. Tissue $\mathrm{K}$ levels increased since the initiation of the study irrespective of treatment, serving as a caution about fertilizers with $\mathrm{K}$ and the risks of excessive $\mathrm{K}$ levels in blueberry. Although this study found no negative consequences associated with postharvest fertilizer $\mathrm{N}$ application timing, results may differ for midand late-fruiting cultivars, for different sources of $\mathrm{N}$ that differ in $\mathrm{N}$ release rates, and in regions with a shorter growing season.

\section{Literature Cited}

Abbott, J.E. and R.E. Gough. 1987. Seasonal development of highbush blueberry roots under sawdust mulch. J. Amer. Soc. Hort. Sci. 112:60-62.

Alexander, M. 1991. Introduction to soil microbiology, 2nd ed. Krieger Publishing Co., Malabar, FL.

Bair, K.E., J.R. Davenport, and R.G. Stevens. 2008. Release of available nitrogen after incorporation of a legume cover crop in concord grape. HortScience 43(3):875-880, https://doi. org/10.21273/HORTSCI.43.3.875.

Bañados, M.P., B.C. Strik, D.R. Bryla, and T.L. Righetti. 2012. Response of highbush blueberry to nitrogen fertilizer during field establishment I: Accumulation and allocation of fertilizer nitrogen and biomass. HortScience 47:648-655, https:// doi.org/10.21273/HORTSCI.47.5.648

Caruso, F.L. and D.C. Ramsdell. 1995. Compendium of blueberry and cranberry diseases. APS Press, St. Paul, MN.

Castrejón, A.D.R., I. Eichholz, S. Rohn, L.W. Kroh, and S. Huyskens-Keil. 2008. Phenolic profile and antioxidant activity of highbush blueberry (Vaccinium corymbosum L.) during fruit maturation and ripening. Food Chem. 109:564-572, https://doi.org/10.1016/j.foodchem.2008.01.007.

Claussen, W. and F. Lenz. 1999. Effect of ammonium or nitrate nutrition on net photosynthesis, growth, and activity of the enzymes nitrate reductase and glutamine synthetase in blueberry, raspberry and strawberry. Plant Soil 208:95-102, https://doi.org/10.1023/A:1004543128899.

Davenport, J.R., K.E. Bair, and R.G. Stevens. 2012. Relationship between soil temperature and $\mathrm{N}$ release in organic and conventionally managed vineyards. Commun. Soil Sci. Plant Anal. 43(1-2):464-470, https://doi.org/10.1080/ 00103624.2012.641838.

Davenport, J.R. and L.W. DeVetter. 2019. Evaluating and revising guidelines for blueberry nutrient standards in Washington. Proc. Western Nutri. Mgmt. Conf. 13:16-17.

Eck, P. 1988. Blueberry science. Rutgers Univ. Press, New Brunswick, NJ.
Fageria, V.D. 2001. Nutrient interactions in crop plants. J. Plant Nutr. 24:1269-1290, https://doi. org/10.1081/PLN-100106981.

Hart, J., B. Strik, L. White, and W. Yang. 2006. Nutrient management for blueberries in Oregon. Ore. State Univ. Ext. Serv. EM 8918.

Krewer, G. and J. Ruter. 2012. Fertilizing bushes three years and older. In: Fertilizing highbush blueberries in pine bark beds. Univ. Ga. Coop. Ext. Bull. 1291.

Korcak, R.F. 1988. Nutrition of blueberry and other calcifuges. Hort. Rev. 10:183-227.

Larco, H., B.C. Strik, D.R. Bryla, and D.M. Sullivan. 2013. Mulch and fertilizer management practices for organic production of highbush blueberry. II: Impact on plant and soil nutrients during establishment. HortScience 48:1484-1495, https://doi. org/10.21273/HORTSCI.48.12.1484.

Mahler, R. L. and D. L. Barney. 2000. Northern Idaho fertility guide: Blueberries, strawberries and raspberries. Univ. of Idaho. Extension Bulletin CIS 815.

Marschner, H. 2011. Marschner's mineral nutrition of higher plants. 3rd ed. Elsevier, Ltd., San Diego, CA.

Mills, L.J., J.C. Ferguson, and M. Keller. 2006. Cold-hardiness evaluation of grapevine buds and cane tissues. Amer. J. Enol. Viticult. 57:194-200.

Mulvaney, R.L. 1996. Nitrogen - Inorganic forms p. 1123-1184. In: J.M. Bigham (ed.). Methods of Soil Analysis Part 3: Chemical Methods. Soil Sci. Soc. of Amer., Madison, WI.

Naraguma, J. and J.R. Clark. 1998. Effect of nitrogen fertilization on 'Arapaho' thornless blackberry. Commun. Soil Sci. Plant Anal. 29(1718):2775-2783, https://doi.org/10.1080/0010362 9809370152

Natural Resources Conservation Service. 2011. Soil quality indicators - Soil electrical conductivity. 4 July 2021. <https://www.nrcs.usda.gov/wps/ portal/nrcs/detailfull//soils/health/assessment/?cid= stelprdb1237387>.

Paniagua, A.C., A.R. East, J.P. Hindmarsh, and J. Heyes. 2013. Moisture loss is the major cause of firmness change during postharvest storage of blueberry. Postharvest Biol. Technol. 79:13-19, https://doi.org/10.1016/j.postharvbio.2012.12.016.

Poonnachit, U. and R. Darnell. 2004. Effect of ammonium and nitrate on ferric chelate reductase and nitrate reductase in Vaccinium species. Ann. Bot. 93:399-405, https://doi.org/10.1093/ aob/mch053.

Raese, J.T. 1997. Cold tolerance, yield, and fruit quality of 'd'Anjou' pears influenced by nitrogen fertilizer rates and time of application. J. Plant Nutr. 20(7-8):1007-1025, https://doi.org/ $10.1080 / 01904169709365313$.

Retamales, J.B. and J.F. Hancock. 2018. Blueberries. 2nd ed. CABI, Wallingford, United Kingdom.

Strik, B.C. 2019. Frequency of harvest affects berry weight, firmness, titratable acidity, and percent soluble solids of highbush blueberry cultivars in Oregon. J. Amer. Pomol. Soc. 73:254-268.

Strik, B.C., A.J. Vance, and C.E. Finn. 2017a. Northern highbush blueberry cultivars differed in yield and fruit quality in two organic production systems from planting to maturity. HortScience 52:844-851, https://doi.org/10.21273/HORTSCI1 1972-17.

Strik, B.C., A. Vance, D.R. Bryla, and D.M. Sullivan. 2017b. Organic production systems in northern highbush blueberry: I: Impact of planting method, cultivar, fertilizer, and mulch on yield and fruit quality from planting through maturity. HortScience 52:1201-1213, https:// doi.org/10.21273/HORTSCI12179-17. 
Strik, B.C., A. Vance, D.R. Bryla, and D.M. Sullivan. 2019. Organic production systems in northern highbush blueberry: II. Impact of planting method, cultivar, fertilizer, and mulch on leaf and soil nutrient concentrations and relationships with yield from planting through maturity. HortScience 54:1777-1794, https:// doi.org/10.21273/HORTSCI14197-19.

Strik, B., G. Buller, and E. Hellman. 2003. Pruning severity affects yield, berry weight, and hand harvest efficiency of highbush blueberry. HortScience 38:196-199, https:// doi.org/10.21273/HORTSCI.38.2.196.

Strik, B. and G. Buller. 2014. Nitrogen fertilization rate, sawdust mulch, and pre-plant incorporation of sawdust - Long-term impact on yield, fruit quality, and soil and plant nutrition in 'Elliott'. Acta Hort. 1017:269-275, https:// doi.org/10.17660/ActaHortic.2014.1017.34.

Sullivan, D. 2015. Compost for blueberry plants Testing and tips. 22 Oct. 2019. < https:// extension.oregonstate.edu/crop-production/berries/ compost-blueberry-plants-testing-tips $>$.

Sweeney, R.A. 1989. Generic combustion method for determination of crude protein in feeds: Collaborative study. J. Assoc. Off. Anal. Chem. 72(5):770-774.

Throop, P.A. and E.J. Hanson. 1997. Effect of application date on absorption of ${ }^{15} \mathrm{~N}$ by highbush blueberry. J. Amer. Soc. Hort. Sci. 122:422-426, https://doi.org/10.21273/ JASHS. 122.3.422.
United States Department of Agriculture Natural Resources Conservation Services (USDANCRS). 2019. Web Soil Survey. 25 Sept. 2019. $<$ https://soilseries.sc.egov.usda.gov/OSD_Docs /W/WARDEN.html>.

Vargas, O.L. and D.R. Bryla. 2015. Growth and fruit production of highbush blueberry fertilized with ammonium sulfate and urea applied by fertigation or as granular fertilizer. HortScience 50:479-485, https://doi.org/10.21273/HORTSCI. 50.3.479.

Zasoski, R.J. and R.G. Burau. 1977. A rapid nitric perchloric acid digestion method of multielement tissue analysis. Commun. Soil Sci. Plant Anal. 3:425-436, https://doi.org/10.1080/0010 3627709366735 . 